\title{
Acute administration of fenproporex increased acetylcholinesterase activity in brain of young rats
}

\author{
BRENA P. TEODORAK ${ }^{1}$, GABRIELA K. FERREIRA ${ }^{1}$, GISELLI SCAINI ${ }^{1}$, LETÍCIA B. \\ WESSLER ${ }^{1}$, ALEXANDRA S. HEYLMANN ${ }^{2}$, PEDRO DEROZA ${ }^{2}$, SAMIRA S. VALVASSORI ${ }^{2}$, \\ ALEXANDRA I. ZUGNO ${ }^{2}$, JOÃO QUEVEDO ${ }^{2}$ and EMILIO L. STRECK ${ }^{1}$ \\ ${ }^{1}$ Programa de Pós-Graduação em Ciências da Saúde, Universidade do Extremo Sul Catarinense, \\ Unidade Acadêmica de Ciências da Saúde, Laboratório de Bioenergética, Av. Universitária, 1105, \\ Bloco S, Sala 6, Bairro Universitário, 88806-000 Criciúma, SC, Brasil \\ ${ }^{2}$ Programa de Pós-Graduação em Ciências da Saúde, Universidade do Extremo Sul Catarinense, \\ Unidade Acadêmica de Ciências da Saúde, Laboratório de Neurociências, Av. Universitária, 1105, \\ Bloco S, Sala 5/ subsolo, Bairro Universitário, 88806-000 Criciúma, SC, Brasil
}

Manuscript received on November 24, 2014; accepted for publication on March 18, 2015

\begin{abstract}
Fenproporex is the second most commonly amphetamine-based anorectic consumed worldwide; this drug is rapidly converted into amphetamine, in vivo, and acts by increasing dopamine levels in the synaptic cleft. Considering that fenproporex effects on the central nervous system are still poorly known and that acetylcholinesterase is a regulatory enzyme which is involved in cholinergic synapses and may indirectly modulate the release of dopamine, the present study investigated the effects of acute administration of fenproporex on acetylcholinesterase activity in brain of young rats. Young male Wistar rats received a single injection of fenproporex $(6.25,12.5$ or $25 \mathrm{mg} / \mathrm{kg}$ i.p.) or vehicle $(2 \%$ Tween 80$)$. Two hours after the injection, the rats were killed by decapitation and the brain was removed for evaluation of acetylcholinesterase activity. Results showed that fenproporex administration increased acetylcholinesterase activity in the hippocampus and posterior cortex, whereas in the prefrontal cortex, striatum and cerebellum the enzyme activity was not altered. In conclusion, in the present study we demonstrated that acute administration of fenproporex exerts an effect in the cholinergic system causing an increase in the activity of acetylcholinesterase in a dose-dependent manner in the hippocampus and posterior cortex. Thus, we suggest that the imbalance in cholinergic homeostasis could be considered as an important pathophysiological mechanism underlying the brain damage observed in patients who use amphetamines such as fenproporex.
\end{abstract}

Key words: Acetylcholinesterase, Amphetamine, Dopamine, Fenproporex.

\section{INTRODUCTION}

Fenproporex is the second most commonly used anorectic substance in the world (Cohen 2009). Fenproporex was synthesized from amphetamine (AMPH) in 1965, in order to increase anorectic

Correspondence to: Emilio L. Streck

E-mail: emiliostreck@gmail.com effect and reduce psychostimulant effect (Fogliatto 1998). Thus, the drug contains the nucleus of betaphenethylamine and the pharmacological action of sympathomimetic amines, acting as an inhibitor of the hypothalamic hunger center, with lipophilic action (Coutts et al. 1986). Fenproporex is an anorectic acting catecholaminergic central nervous 
system is widely used in the short-term treatment of moderate to severe obesity since 1970 (Bell et al. 2001). Fenproporex promotes the reduction of food intake, through a change in the chemical control of nerve impulse transmission; the drugs presents a similar effect to that of amphetamine, including central nervous system stimulation, which acts by blocking the reuptake of norepinephrine and dopamine, thereby increasing the levels of these neurotransmitters in the synaptic cleft (Coutts et al. 1986).

Amphetamine compounds, including fenproporex, are classified as indirect-acting dopaminergic agents. These compounds have complex actions on the noradrenaline and dopamine presynaptic terminal, releasing or blocking neuronal reuptake of noradrenaline and dopamine. The end result of the actions of amphetamines in dopaminergic terminals is an increased concentration of dopamine in the synaptic cleft. The dopamine interacts with the dopamine D1 and D2 initiating a sequence of events that modifies neural activity and finally the expression behavior (Coutts et al. 1986, Hyman et al. 1996, Mattei and Carlini 1996). The dopamine system is among the most important neurotransmitter systems and its relationship to the cholinergic system has been widely studied (Hefco et al. 2004).

Acetylcholine (ACh) is one of the most studied excitatory neurotransmitter in the central nervous system. It is synthesized from acetyl coenzyme A (acetyl CoA) formed during cell respiration and choline, an important product of the metabolism of lipids (Taylor and Brown 1994, Soreq and Seidman 2001). It is important in the functions performed by the central nervous system, and has been associated with cognitive function, information processing sensory cortical organization of movement and control of cerebral blood flow (Scremin et al. 1997). Cholinergic transmission is mainly terminated by ACh hydrolysis by the enzyme acetylcholinesterase (AChE: EC 3.1.1.7), catalyzing the hydrolysis of ACh to choline and acetic acid (Marcel et al. 1998). $\mathrm{AChE}$ is one of the most important enzymes in many living organisms, including vertebrates and humans. It is essential to the normal functioning of the nervous system, since it rapidly terminates the action of ACh released into the synapse (Soreq and Seidman 2001). AChE is associated with brain development, learning, memory and neuronal damage (Ballard et al. 2005, Metz and Tracey 2005, Zimmerman and Soreq 2006). Moreover, it has also been reported that cholinesterase is involved in modulating glial activation, cerebral blood flux, amyloid cascade, and tau phosphorylation as well as acts as an adhesion protein in synaptic development and maintenance (Ballard et al. 2005, Silman and Sussman 2005).

Considering that fenproporex is rapidly converted in vivo into amphetamine leading to increased extracellular dopamine levels in brain and that $\mathrm{AChE}$ is an enzyme regulator involved in cholinergic transmission and can indirectly modulate dopamine release, the present study investigated the effects of acute administration of fenproporex on the enzyme activity of $\mathrm{AChE}$ in brain of young rats.

\section{MATERIALS AND METHODS}

\section{ANIMALS}

Young male Wistar rats (100 - $120 \mathrm{~g})$ were obtained from the Central Animal House of Universidade do Extremo Sul Catarinense. The animals were caged in groups of 5 with free access to food and water, maintained on a 12-h light-dark cycle (lights on 7:00 am), at a temperature of $23 \pm 1^{\circ} \mathrm{C}$. All experimental procedures were carried out in accordance with the "Principles of Laboratory Animal Care" (NIH publication no. 80-23, revised 1996) and the Brazilian Society for Neuroscience and Behavior $(\mathrm{SBNeC})$ recommendations for animal care, with the approval of UNESC Ethics Committee (protocols number 43/2009). Moreover, all efforts were made to minimize animal suffering as well as to use a reduced number of animals. 


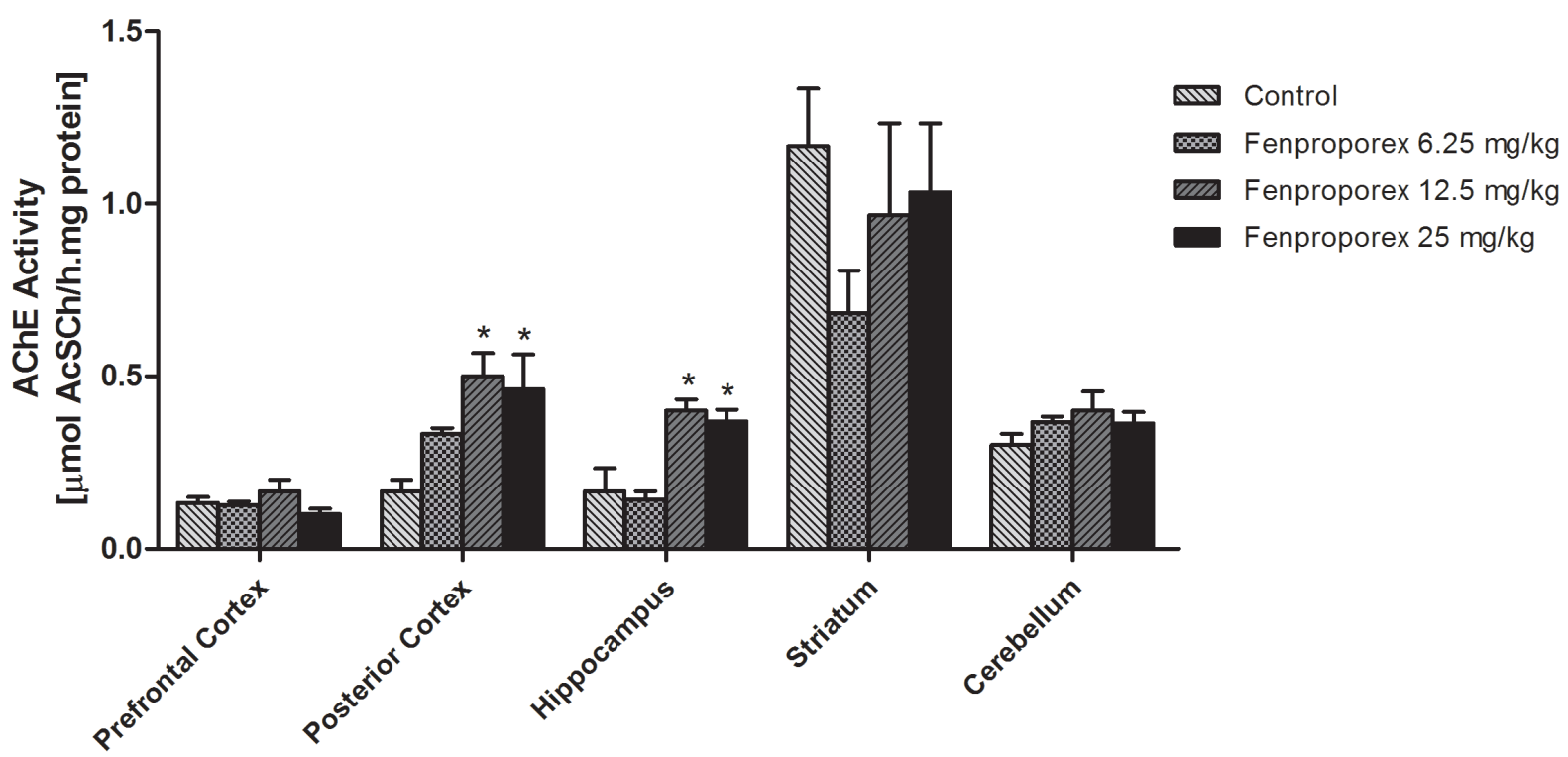

Figure 1 - Acetylcholinesterase activity after acute administration of fenproporex. Data were analyzed by one-way analysis of variance followed by Tukey test when F was significant. Values are expressed as $\mu$ mol AcSCh/h.mg protein, mean \pm S.D. (n=6). *Different from control; $\mathrm{p}<0.05$.

\section{ACUTE ADMINISTRATION OF FENPROPOREX}

Animals received a single intraperitoneal injection of Fen $(6.25 ; 12.5$ or $25 \mathrm{mg} / \mathrm{kg}$, ) or vehicle $(2 \%$ Tween 80 in $0.9 \%$ physiological saline solution). The administration schedule was chosen on the basis of experiments previously performed in our laboratory (Rezin et al. 2014). Two hours after the injection the animals were killed by decapitation without anesthesia and the brain was excised on a Petri dish placed on ice. Prefrontal cortex, posterior cortex, hippocampus, striatum and cerebellum were homogenized in a $100 \mathrm{mM}$ phosphate buffer containing $0.1 \%$ Triton $\mathrm{X}-100, \mathrm{pH} 7.5$. The homogenates were centrifuged at $800 \mathrm{x} \mathrm{g}$ for 10 min at $4{ }^{\circ} \mathrm{C}$ and the supernatants were isolated and used for the evaluation of acetylcholinesterase activity.

\section{ACHE ACTIVITY}

AChE activity was assayed according to the method of Ellman et al. (1961). The reaction mixture (2 $\mathrm{ml}$ final volume) contained $100 \mathrm{mM} \mathrm{K}$-phosphate

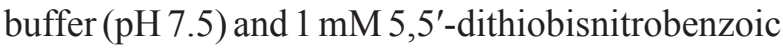
acid. The method is based on the formation of the yellow anion, 5,5'-dithio-bis-acid-nitrobenzoic, which is measured by absorbance at $412 \mathrm{~nm}$ during a 2-min incubation at $25^{\circ} \mathrm{C}$. The enzyme (40-50 $\mu \mathrm{g}$ of protein) was preincubated for $2 \mathrm{~min}$. The reaction was initiated by adding $0.8 \mathrm{mM}$ acetylthiocholine iodide (AcSCh). All samples were run in duplicate or triplicate, and the enzyme activity is expressed in micromoles AcSCh per hour per milligram of protein. The protein levels were measured using the method of Lowry et al. (1951) with bovine serum albumin as the standard.

\section{STATISTICAL ANALYSES}

The results are presented as the mean \pm the standard deviation. Tests for determining normality and equal variances were performed to examine whether the data qualified for parametric statistical tests. The data were normally distributed (ShapiroWilk, $p>0.05$ ) with equal variances among samples 
(equal variances test, $\mathrm{p}>0.05$ ). Therefore, a oneway analysis of variance (ANOVA) followed by Tukey HSD post-hoc tests were used to compare the means. The differences between groups were considered to be significant at $p<0.05$. All of the analyses were carried out on an IBM-compatible PC computer using Statistical Package for the Social Sciences (SPSS) software (Armonk, New York, USA).

\section{RESULTS}

We evaluated the effect of acute administration of fenproporex at three different doses on AChE activity in prefrontal cortex, cerebellum, hippocampus, striatum and posterior cortex of young rats. Acute administration of fenproporex increased the AChE activity in the hippocampus $(12.5$ and $25 \mathrm{mg} / \mathrm{kg}$ ) and posterior cortex (12.5 and $25 \mathrm{mg} / \mathrm{kg}$ ) (Fig. 1). Moreover, AChE activity was not altered in the prefrontal cortex, striatum and cerebellum after acute administration of fenproporex $(6.25 \mathrm{mg} / \mathrm{kg}, 12.5 \mathrm{mg} / \mathrm{kg}$ and $25 \mathrm{mg} /$ $\mathrm{kg}$ ), when compared with control group.

\section{DISCUSSION}

Fenproporex is an amphetamine-derived anorectic which is rapidly converted in vivo into amphetamine, used in obesity treatment. Consumption of a low daily dose, $10 \mathrm{mg}$, of fenproporex led to the detection of amphetamine, within 3 hours, in urine with peak urinary levels greater than $4.0 \mathrm{ng} / \mathrm{mL}$ (Cody et al. 1986). Silva et al. (2010) suggested that high concentrations of amphetamine are neurotoxic and can cause irreversible damage to serotonergic or dopaminergic neurons in brain. The mechanisms of neurotoxicity induced by fenproporex and amphetamine are mediated by multiple mechanisms, including the production of free radicals (Frey et al. 2006, Valvassori et al. 2008), DNA damage (Atianjoh et al. 2008, Gonçalves et al. 2013), mitochondrial dysfunction (Valvassori et al. 2010, Rezin et al. 2011, 2014, Feier et al. 2012), changes in $\mathrm{Na}+, \mathrm{K}+$-ATPase activity (Rezin et al. 2013) and mitochondrial apoptotic pathway through cytochrome c release (Oliveira et al. 2003, Jiménez et al. 2004).

$\mathrm{ACh}$ as a neurotransmitter has a crucial role in the central nervous system and is implicated in behavioral as well as learning and memory and neurodegenerative diseases (Berger-Sweeney et al. 2003, Schliebs and Arendt 2006). AChE activation leads to a fast acetylcholine degradation and a subsequent down stimulation of $\mathrm{ACh}$ receptors causing undesirable effects on cognitive functions (Tõugu and Kesvatera 1996, Soreq and Seidman 2001). Our results showed that acute administration of fenproporex in young rats increased AChE activity in the hippocampus and posterior cortex, further suggesting that fenproporex, in high doses, can have a neurotoxic effect on the cholinergic system. Considering these findings we speculate that increased AChE activity caused by fenproporex may lead to a reduction of cholinergic neurotransmission efficiency due to a decrease in ACh levels in the synaptic cleft, thus contributing to progressive cognitive impairment. In addition, several lines of evidence (Greenfield 1984, Inestrosa et al. 1996, Karpel et al. 1996, Layer and Willbold 1995) demonstrate non-catalytic activities for $\mathrm{AChE}$, indicating that the enzyme plays a complex role in modulating cell growth and death. Jiang and Zhang (2008) showed that AChE isoforms participate in apoptosis in two ways: by promoting or suppressing cell death. Enhanced AChE variant expression may influence the expression of other group genes, including those involved in apoptosis (Ben-Ari et al. 2006).

Interestingly, $\mathrm{AChE}$ responds to various insults including oxidative stress. Alterations in the lipid membrane observed after fenproporex administration(Model etal.2014) could be a decisive factor in the modification of conformational state of the AChE molecule and would explain changes in its activity (Das et al. 2001, Aldunate et al. 2004). It is well described in literature that psychostimulants have serious side effects and particular behavioral changes and is a potential for abuse. It is known 
that amphetamine induces generation of free radicals via the oxidative catabolism of dopamine, suggesting that dopamine autoxidation can form reactive quinones that attack and potentially inhibit the function of intracellular proteins (LaVoie and Hastings 1999, Page et al. 2001). In addition to dopamine autoxidation, metabolism of dopamine by monoamine oxidase can incrase the production of $\mathrm{H}_{2} \mathrm{O}_{2}$ and iron-dependent reactive oxygen species (Spina and Cohen 1989). Based on these observations, we can suggest that $\mathrm{AChE}$ activation after acute administration of Fen may be mediated by the production of free radical production and consequent oxidative stress in the different brain regions.

Our results also indicate that acute administration of fenproporex did not alter AChE activity in prefrontal cortex, cerebellum and striatum. One possible explanation for the lack of fenproporex effect in these areas is the fact that there are a wide variety of molecular shapes of AChE, which differ in the type and solubility of the membrane binding, rather than catalytic activity (Das et al. 2001). Moreover, the brain is a complex biological structure, consisting of several regions which respond differently and, in part, to different types of neurons. Thus, within a homogeneous population of cells, there is great heterogeneity in terms of physiological and metabolic diseases (Sonnewald et al. 1998). Another important point to consider here are the different effects observed after acute and chronic administration of Fen in young and adult rats. Rezin et al. (2012) showed that chronic fenproporex administration in adult rats decreases AChE activity in prefrontal cortex and striatum, whereas our results showed that $\mathrm{AChE}$ activity was increased in hippocampus and posterior cortex after acute administration of fenproporex in young rats. The reason for these discrepancies is unknown but the different effects can be explained by the fact that juvenile and adolescent brain are highly plastic and develop rapidly, so they may be vulnerable to the actions of chronic drug treatment (Kuczenski and Segal 2005). Moreover, excessive stimulation of dopamine receptors during exposure to psychostimulants induces various molecular adaptive changes in the brain (Burrone and Murthy 2003, Nestler 2004). On the other hand, this agerelated difference may be caused by pruning of synapses and receptors in adult animals. An overproduction of synapses and receptors from infancy to pubertal onset is followed by a pruning to adult levels during the transition from adolescence to adulthood (Huttenlocher 1979). Thus, it is possible that these molecular adaptive changes could be responsible for the differences in AChE activity observed between young and adult rats.

In conclusion, in the present study we demonstrated that acute administration of fenproporex exerts an effect in the cholinergic system, by altering AChE activity. Our results demonstrated that acute administration of fenproporex increased AChE activity in a dosedependent manner in the hippocampus and posterior cortex of rats. Thus, considering the present findings, we suggest that the imbalance in cholinergic homeostasis could be considered an important pathophysiological mechanism underlying the brain damage observed in patients who use amphetamines such as fenproporex.

\section{ACKNOWLEDGMENTS}

This work was supported by grants from Programa de Pós-Graduação em Ciências da Saúde - Universidade do Extremo Sul Catarinense (UNESC), Núcleo de Excelência em Neurociências Aplicadas de Santa Catarina (NENASC), Conselho Nacional de Desenvolvimento Científico e Tecnológico (CNPq) and Instituto Nacional de Ciência e Tecnologia Translacional em Medicina (INCT).

\section{RESUMO}

O femproporex é o segundo anorexígeno à base de anfetamina mais consumido no mundo; esse fármaco é rapidamente convertido in vivo em anfetamina e atua através do aumento dos níveis de dopamina na fenda 
sináptica. Considerando que os efeitos do femproporex sobre o Sistema Nervoso Central são ainda pouco conhecidos e que a acetilcolinesterase é uma enzima reguladora envolvida na transmissão colinérgica e que indiretamente pode modular a liberação de dopamina, o presente estudo investigou os efeitos da administração aguda de femproporex sobre a atividade da enzima acetilcolinesterase em cérebro de ratos jovens. Ratos Wistar machos jovens receberam uma única injeção de femproporex $(6,25,12,5$ ou $25 \mathrm{mg} / \mathrm{kg}$ i.p.) ou veículo (Tween 80 2\%). Duas horas após a injeção, os ratos foram mortos por decapitação e o cérebro foi removido para avaliação da atividade da acetilcolinesterase. Os resultados mostraram que a administração de femproporex aumentou a atividade da acetilcolinesterase no hipocampo e córtex posterior, enquanto que no córtex pré-frontal, estriado e cerebelo a atividade da enzima não foi alterada. Em conclusão, o presente estudo demonstrou que a administração aguda de femproporex exerce um efeito no sistema colinérgico causando um aumento na atividade da acetilcolinesterase, de um modo dose dependente, no hipocampo e córtex posterior. Assim, sugere-se que o desequilíbrio na homeostase colinérgica pode ser considerado um importante mecanismo fisiopatológico subjacente ao dano cerebral observado em pacientes que utilizam anfetaminas, como o femproporex.

Palavras-chave: Acetilcolinesterase, Anfetamina, Dopamina, Femproporex.

\section{REFERENCES}

ALdunATE R, CASAR JC AND BRANDAN E. 2004 Structural and functional organization of synaptic acetylcholinesterase. Brain Res Rev 47: 96-104.

ATIANJOH FE, LADENHEIM B, KRASNOVA IN AND CADET JL. 2008. Amphetamine causes dopamine depletion and cell death in the mouse olfactory bulb. Eur J Pharmacol 589: 94-97.

BALlard CG, GREIG NH, GuILlOZET-BongAarts AL, ENZ A AND DARVESH S. 2005. Cholinesterases: Roles in the brain during health and disease. Curr Alzheimer Res 2: 307-318.

BELl RR, CROOKHAM SB, DUNN WA, GRATES KM AND REIBER TM. 2001. A contemporaneous finding of fenproporex in a polydrug suicide. J Anal Toxicol 25: 652-656.

Ben-Ari S, Toiber D, SAS AS, Soreq H AND Ben-Shaul Y. 2006. Modulated splicing-associated gene expression in P19 cells expressing distinct acetylcholinesterase splice variants. J Neurochem 97: 24-34.
BERGER-SWEENEY J. 2003. The cholinergic basal forebrain system during development and its influence on cognitive processes: important questions and potential answers. Neurosci Behav Rev 27: 401-411.

BurRone J AND MurThy VN. 2003. Synaptic gain control and homeostasis. Curr Opin Neurobiol 13: 560-567.

Cody JT, Valtier S And Stillman S. 1999. Amphetamine and fenproporex levels following multidose administration of fenproporex. J Anal Toxicol 23: 187-194.

COHEN PA. 2009. Imported fenproporex-based diet pills from Brazil: a report of two cases. J Gen Intern Med 24: 430-433.

Coutts RT, Nazarali AJ, BAKer GB ANd Pasutto FM. 1986. Metabolism and disposition of N-(2-cyanoethyl)amphetamine (fenproporex) and amphetamine: study in the rat brain. Can J Physiol Pharmacol 64: 724-728.

DAS A, KAPOOR K, SAYEEPRIYADARSHINI AT, DIKSHIT M, PALIT G AND NATH C. 2000. Immobilization stressinduced changes in acetylcholinesterase activity and cognitive function in mice. Pharmacol Res 42: 213-217.

Ellman GI, Courtney KD, Andres JR V AND FeatherStone RM. 1961. A New and Rapid Colorimetric Determination of Acetylcholinesterase Activity. Biochem Pharmacol 7: 88-95.

Feier G, VAlvassori SS, Lopes-Borges J, VARela RB, Bavaresco DV, Scaini G, Morais MO, ANDERSEN ML, STRECK EL AND QueVEDO J. 2012. Behavioral changes and brain energy metabolism dysfunction in rats treated with methamphetamine or dextroamphetamine. Neurosci Lett 530: 75-79.

FogLiATto MR. 1998. Ecstasy-aspectos gerais da MDMA e outras anfetaminas de anel substituído. Revista do IGP, Porto Alegre 58: 19.

Frey BN, Martins MR, Petronilho FC, Dal-Pizzol F, QUEVEDO J AND KAPCZINSKI F. 2006. Increased oxidative stress after repeated amphetamine exposure: possible relevance as a model of mania. Bipolar Disord 8: 275-280.

GONÇALVES CL ET AL. 2013. Effects of acute and chronic administration of fenproporex on DNA damage parameters in young and adult rats. Mol Cell Biochem 380: 171-176.

GREENFIELD S. 1984. Acetylcholinesterase may have novel functions in the brain. Trends Neurosci 7: 364-368.

Hefco V, Yamada K, Hefco A, Hritcu L, Tiron A And NABEShimA T. 2004. The interaction between the cholinergic and dopaminergic system in learning and memory process in rats. Rom J Physiol 41: 21-30.

HUTTENLOCHER PR. 1979. Synaptic density in human frontal cortex - developmental changes and effects of aging. Brain Res 163: 195-205.

HYMAN SE. 1996. Addiction to cocaine and amphetamine. Neuron, Cambridge 16: 901-904.

Inestrosa NC, Alvarez A, Pérez CA, Moreno RD, Vicente M, Linker C, CASANUEVA OI, Soto C AND GARRIDO J. 1996. Acetylcholinesterase accelerates assembly of amyloid-b-peptides into Alzheimer's fibrils: 
possible role of the peripheral site of the enzyme. Neuron 16: 881-891.

JIANG H AND ZHANG XJ. 2008. Acetylcholinesterase and apoptosis. A novel perspective for an old enzyme. FEBS J 275: 612-617.

JimÉnEZ A, JordÀ EG, Verdaguer E, Pubill D, SuREdA FX, Canudas AM, Escubedo E, CAmarasa J, CAmins A AND PALLÀS M. 2004. Neurotoxicity of amphetamine derivatives is mediated by caspase pathway activation in rat cerebellar granule cells. Toxicol Appl Pharmacol 196: 223-234.

Karpel R, Sternfeld M, Ginzberg D, Guhl E, GRAESSMANN A AND SOREQ H. 1996. Overexpression of alternative human acetylcholinesterase forms modulates process extensions in cultured glioma cells. J Neurochem 66: 114-123.

Kuczenski R And SEgal DS. 2005. Stimulant actions in rodents: Implications for attention-deficit/hyperactivity disorder treatment and potential substance abuse. Biol Psychiatry 57: 1391-1396.

LaVoie MJ And Hastings TG. 1999. Dopamine quinone formation and protein modification associated with the striatal neurotoxicity of methamphetamine: evidence against a role for extracellular dopamine. J Neurosci 19: 1484-1491.

LAYER P AND Willbold E. 1995. Novel functions of cholinesterases in development, physiology and disease. Prog Hisotchem Cytochem 29: 1-92.

LOWry OH, Rosebrough NJ, FARr AL AND RANDALL RJ. 1951. Protein measurement with the Folin phenol reagent. J Biol Chem 193: 265-275.

Marcel V, Palacios LG, Pertuy C, Masson P and FOURNIER D. 1998. Two invertebrate acetylcholinesterases show activation followed by inhibition with substrate concentration. Biochem J 329: 329-334.

MATTEI R AND CARLINI EA. 1996. Acomparative study of the anorectic and behavioral effects of fenproporex on male and female rats. Braz J Med Biol Res 29: 1025-1030.

METZ CN AND TRACEY KJ. 2005. It takes nerve to dampen inflammation. Nat Immunol 6: 756-757.

Model CS ET AL. 2014. Omega-3 fatty acids alter behavioral and oxidative stress parameters in animals subjected to fenproporex administration. Metab Brain Dis 29: 185-192.

NESTLER EJ. 2004. Molecular mechanisms of drug addiction. Neuropharmacology 47: 24-32.

Oliveira MT, Rego AC, Macedo TR AND Oliveira CR. 2003. Drugs of abuse induce apoptotic features in PC12 cells. Ann N Y Acad Sci 1010: 667-670.

Page G, Peeters M, Najimi M, Maloteaux JM And HERMANS E. 2001. Modulation of the neuronal dopamine transporter activity by the metabotropic glutamate receptor mGluR5 in rat striatal synaptosomes through phosphorylation mediated processes. J Neurochem 76 : 1282-1290.
REZIN GT ET AL. 2014. Fenproporex increases locomotor activity and alters energy metabolism, and mood stabilizers reverse these changes: a proposal for a new animal model of mania. Mol Neurobiol 49: 877-892.

Rezin GT, Jeremias IC, Ferreira GK, Cardoso Mr, Morais MO, GOMES LM, MARTINELlo OB, VALVASSORI SS, Quevedo J AND STRECK EL. 2011. Brain energy metabolism is activated after acute and chronic administration of fenproporex in young rats. Int $\mathrm{J}$ Dev Neurosci 29: 937-942.

REZIN GT ET AL. 2012. Inhibition of acetylcholinesterase activity in brain and behavioral analysis in adult rats after chronic administration of fenproporex. Metab Brain Dis 27: 453-458.

SCHLIEBS R AND ARENDT T. 2006. The significance of the cholinergic system in the brain during aging and in Alzheimer's disease. J Neural Transm 113: 1625-1644.

SCREMIN OU, Li MG, SCREMIN AM AND Jenden DJ. 1997. Cholinesterase inhibition improves blood flow in the ischemic cerebral cortex. Brain Res Bull 42: 59-70.

Silman I AND Sussman JL. 2005. Acetylcholinesterase: 'classical' and 'non-classical' functions and pharmacology. Curr Opin Pharmacol 5: 293-302.

Silva CJ, Dos SANTOS JE AND SATIE TAKAHASHI C. 2010. An evaluation of the genotoxic and cytotoxic effects of the anti-obesity drugs sibutramine and fenproporex. Hum Exp Toxicol 29: 187-197.

Sonnewald U, Hertz L AND Schousboe A. 1998. Mitochondrial heterogeneity in the brain at the cellular level. J Cereb Blood Flow Metab 18: 231-237.

SOREQ H AND SEIDMAN S. 2001. Acetylcholinesterase - new roles for an old actor. Nat Rev Neurosci 2: 294-302.

SPINA MB AND COHEN G. 1989 Dopamine turnover and glutathione oxidation: implications for Parkinson disease. Proc Natl Acad Sci USA 86: 1398-1400.

TAYLOR SE AND BROWN JD. 1994. Positive illusions and wellbeing revisited; Separating fact from fiction. Psycho Bull Psychological Bulletin 116: 21-27.

TÕUGU V AND KESVATERA T. 1996. Role of ionic interactions in cholinesterase catalysis. Biochim Biophys Acta 1298: 12-30.

VAlVAssori SS, Petronilho FC, RÉUs GZ, Steckert AV, Oliveira VB, BOECK CR, KAPCZINSKi F, DAL-Pizzol F AND QUEVEDO J. 2008. Effect of N-acetylcysteine and/or deferoxamine on oxidative stress and hyperactivity in an animal model of mania. Prog Neuropsychopharmacol Biol Psychiatry 32: 1064-1068.

VALVASSOri SS, REZIN GT, FERreira CL, Moretti M, GONÇALVES CL, CARDOSO MR, STRECK EL, KAPCZINSKI F AND QUEVEDO J. 2010. Effects of mood stabilizers on mitochondrial respiratory chain activity in brain of rats treated with d-amphetamine. J Psychiatr Res 14: 903-909.

ZIMMERMAN G AND SOREQ H. 2006. Termination and beyond: Acetylcholinesterase as a modulator of synaptic transmission. Cell Tissue Res 326: 655-669. 